Branislav Marković ${ }^{1 *}$, Miroslav Sokić ${ }^{1}$, Ilija llić2 Vaso Manojlović ${ }^{1}$, Zvonko Gulišija ${ }^{1 *}$, Dragana Živković3" Nada Štrbac ${ }^{3}$

${ }^{1}$ Institute for technology of nuclear and other mineral raw materials, Belgrade, ${ }^{2}$ University of Belgrade, Faculty of Technology and Metallurgy, Belgrade, ${ }^{3}$ University of Belgrade, Technical Faculty Bor, Bor, "Academy of Engineering Sciences of Serbia, Belgrade, Serbia
Scientific paper

ISSN 0351-9465, E-ISSN 2466-2585

UDC: $620.97: 669.002 .8$

doi:10.5937/ZasMat1701100M

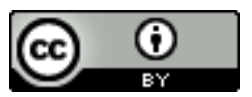

Zastita Materijala 58 (1)

$100-103(2017)$

\title{
Exergy concept and its implementation in the recycling of metals
}

\begin{abstract}
Modern industrial product design implies presence of many different materials. Consequently, in the recycling process, shredding and separation procedures are applied. However, all materials cannot be completely separated; therefore, there is a contamination in the recycling streams. The quality of the materials streams can be reduced in each of the following recycling steps. These qualitative losses cannot be described by material balance. This paper presents the concept of exergy as a measure of quality losses, and gives the methods for the calculation of the exergy content and the exergy loss. Losses attributed to the recycling or material losses, material contamination losses and dilution requirements can be used as indicators for the materials quality loss as well as for the resource efficiency in the production systems. In this paper, the example of calculations on the steel scrap is presented.
\end{abstract}

Keywords: exergy concept, recycling, contamination, quality losses.

\section{INTRODUCTION}

Modern industrial product represents a combination of a large number of different materials related in more or less complex sets. Consequently, the complete dismantling of these end-of-life products would be too expensive. Instead of dismantling, in the recycling factories, shredding and separation processes are applied. During the shredding process, products are broken into the smaller pieces in order to release the materials contained in them. Often the joints between different materials are not completely separated causing contamination of the recycling streams, so that impurities occur in the recycled materials [1]. Typically, the resources are not lost from the resource production cycle, but their quality decreases after each life cycle. The common solution for contaminated material streams are adding the new quantities of pure material to dilute undesired impurities and thus increase the quality of this material.

Mass balance will not provide a complete picture of the resource using efficiency, so it is necessary to define universal measure for quality

${ }^{*}$ Corresponding author: Branislav Marković

E-mail: b.markovic@itnms.ac.rs

Paper received: 18. 10. 2016.

Paper accepted: 21. 11. 2016.

Paper is available on the website: www.idk.org.rs/journal losses during the recycling process. The suitable measure for quality losses is exergy, which provides high potential for system analysis in many scientific fields [2-7].

\section{EXERGY CONCEPT AND QUALITY LOSSES IN THE METAL RECYCLING PROCESS}

Exergy can be considered as a measure of the available energy in thy system [8]. The combination of the first and second laws of thermodynamics:

$$
\begin{aligned}
& d U=\delta Q+\delta W \\
& d S=\delta Q / T
\end{aligned}
$$

has led to the definition of the exergy concept, introduced by Rant, in year 1953 [8]. Exergy $(\dot{E})$ of a certain energy sources or matter indicates its ability or capacity to produce the work, or to cause a change in the system, or local environment [9]. Based on this definition exergy of the system can be defined by the general equation [9]:

$$
\dot{E}=W=U_{1}-U_{2}-T_{0}\left(S_{1}-S_{2}\right)
$$

where $U$ is the internal energy of the system. Unlike energy, exergy is consumed in all real processes in which the entropy is produced. Exergy consumption refers to the sum of produced entropy [9]:

$$
\Delta \dot{E}=T_{0} \Sigma \Delta S
$$

where $T_{0}$ is a reference temperature and $S$ the entropy of the system. Exergy $(\dot{E})$ is a thermodynamic measure for change in the structure of the 
material. Therefore, exergy losses can describe the material quality losses during the recycling process.

For specific applications, the equation (4) can be further developed in a various form [10]. The content of the chemical exergy of the mixture can be calculated by [11]:

$\dot{e}_{c h, m i x}=\sum_{i} x_{i}\left[\dot{e}_{0 i}+R T_{0} \ln \left(\gamma_{i} x_{i}\right)\right]$

where $\dot{e}_{O i}$ is a standard chemical exergy of component $i ; R$ is a molar gas constant; $T_{0}$ is a temperature in the reference condition; $x$ a mole fraction; and $\gamma_{i}$ is the activity coefficient of component $i$ in the mixture. This equation is used to calculate the exergy content for the metal alloys and for the calculation of exergy loss due to changes in the alloys composition, as a result of the contamination.

Quality losses during the recycling process can be described as exergy loss in the material. For the calculation of exergy loss during the recycling process of end-of-life vehicles (ELV), emphasis is placed on metal alloys, because they are the most relevant material in passenger vehicles from the environment point of view.

Losses during the metallurgical recycling of metals can be classified into the three different types: losses of the first, second and third order. Losses of the first order correspond to the amount of material that is lost in a landfill after shredding and separation, and in the slug during the melting process These losses lead to a decrease of the exergy in the system due to the loss of matter, and can be calculated with equation (5) multiplying the specific exergy of each component in the lost material with a weight of lost material.

Losses of the second order occur during the melting process. When contaminants (impurities) are present, they are dissolved in the molten metal, increasing the entropy of alloys (i.e. increasing the disorder of the system). This will ultimately lead to the recycled alloys properties deterioration, in comparison with the primary alloy, so these loses are referred to the losses of system quality. Losses of the second order can be calculated adjusting equation (5) as

$$
\Delta \dot{E}_{\text {ch,mix }}=\sum_{i} x_{i} m_{i}\left[\dot{e}_{0 i}+R T_{0} \ln \left(\gamma_{i} x_{i}\right)\right]_{f i n}-\sum_{i} x_{i} m_{i}\left[\dot{e}_{0 i}+R T_{0} \ln \left(\gamma_{i} x_{i}\right)\right]_{\text {init }}
$$

where $m_{i}$ is mass fraction of each component, and init and fin are related to the state before and after melting process, respectively.

Losses of the third order occur because of the possible need for diluting of contaminants, when they content exceed the maximum limitation for a given alloy. Additional high purity resources must be added to dilute the contaminant to an acceptable level or original level. These losses can be directly calculated from equation (5) by multiplying each specific exergy of the component in material for dilution with the mass of the same component required for dilution. The exergy efficiency is calculated using equation (7) where the ratio between the sum of all exergy losses is divided by the sum of all exergy added to the system [9]:

$$
\Psi=\sum \Delta \dot{E}_{\text {out }} / \sum \Delta \dot{E}_{\text {in }}=\frac{\left(\dot{E}_{\text {out }}-\dot{E}_{\text {loss }}\right), \text { which is alway s lower than } 1}{\dot{E}_{\text {in }}}
$$

where $\dot{E}_{i n}$ is the sum of all exergy entering to the system, $\dot{E}_{\text {out }}$ the sum of all exergy leaving the system and $\dot{E}_{\text {loss }}$ is the exergy lost during the analysed process. The exergy efficiency is always lower than unity in real processes. Another measure of the efficiency of resources use in the products life cycles can be defined as resource input ratio, R.I. This measure accounts the ratio between the resource inputs required for dilution during recycling and the input material to be recycled:

$$
\mathrm{RI}=\left(\frac{\dot{E}_{\text {input }}}{\dot{E}_{\text {in }}}\right)
$$

The term $\dot{E}_{\text {input }}$ regards the exergy content of the resources required for dilution, i.e., the third order losses, and the $\dot{E}_{\text {in }}$ regards the exergy content of the initial material to be recycled.

\section{RESULTS AND DISCUSSION}

Knowing the amount of exempt and nonexempt material in a waste for the melting, mass balance allows us to calculate the composition of the alloy, produced by melting a mixture of exempt 
and non-exempt metals. Thermo-Calc software [12] calculates the activity of all components in the solution, for a given temperature, pressure and their mass fractions. With activity and weight ratio data, total exergy content of the alloy can be calculated using equation (5), while losses can be calculated using equation (5) and (6). The impact of contaminations in alloys on the exergy content can be illustrated on the example of aluminum in secondary steel production process.

Suppose that $550 \mathrm{~kg}$ of steel scrap containing 5 $\mathrm{kg}$ of aluminum contamination from electric motors and other ELV parts. Estimated total first order losses of the steel are $50 \mathrm{~kg}$ (it is assumed that only steel was lost, to simplify calculation), so in the system remains $500 \mathrm{~kg}$ of waste. With this waste the lower quality of steel will be produced that meets the requirements of the standard for quality EN10111/2008 for production of automobile wheels, and contains $0,45 \% \mathrm{Al}$, (maximal content of $\mathrm{Al}$ in practice).

In order to achieve this, it is necessary to add $610 \mathrm{~kg}$ of pure steel scrap. It is assumed that both aluminum and steel have purity of $100 \%$. Mixture 1 is waste before melting process, alloy 2 is melted waste, and alloy 3 steel after dilution. The data and the composition of the alloy are presented in Table 1.

Table 3. Exergy content and exergy losses due to contamination with aluminum

Tabela 3. Eksergijski sadržaj i eksergijski gubici usled kontaminacije aluminijumom

\begin{tabular}{|c|c|c|c|c|c|c|}
\hline \multirow{2}{*}{ Material } & $\dot{e}_{\text {ch }}\left(\mathrm{MJ} \mathrm{kg}^{-1}\right)$ & Mass $(\mathrm{kg})$ & $\dot{E}_{\mathrm{ch}}(\mathrm{MJ})$ & \multicolumn{3}{|c|}{$\dot{E}$ Losses $(\mathrm{MJ})$} \\
\cline { 2 - 7 } & $(1)$ & $(2)$ & $(1 \times 2)$ & 1st order & 2nd order & 3rd order \\
\hline Alloy 1 (Fe) & 6.7398 & 545 & 3673.2 & 337.0 & & \\
\hline Mix 1 (Fe) & 6.7398 & 495 & 3336.2 & & & \\
\hline Mix 1 (Al) & 32.105 & 5 & 160.5 & & & \\
\hline Alloy 2 & 6.8560 & 500 & 3428.0 & & 68.7 & \\
\hline Dilution alloy & 6.7398 & 610 & 4111.3 & & & 4111.3 \\
\hline Alloy 3 & 6.8108 & 1110 & 7560.0 & & 20.7 & \\
\hline
\end{tabular}

The first order losses correspond to a loss during the recycling process. The second order losses correspond to the reduction of specific exergy $\left(\dot{e}_{\mathrm{ch}}\right)$ due to the contaminants dissolving, which is in total 89.4 MJ. The third order losses correspond to the added amount of exergy in the system as the diluted material. It is evident that the losses of third order are dominant. This is due to the high material dilution $(610 \mathrm{~kg})$ which is necessary to produce alloy 3 . Although, the third order losses are not the losses from the system (defined limits of the system does not include reserves of resources, but only the amount of material for recycling), it can be argued that this material is "exhausted" from resource reserves, and therefore can be considered as recycling loss. From the Table 3 it is obvious that specific content
Table 1. The amount and composition of various alloys

Tabela 1. Količina i sastav različitih legura

\begin{tabular}{|l|c|c|c|}
\hline \multirow{2}{*}{ Alloy/Mix } & \multirow{2}{*}{ Mass (kg) } & \multicolumn{2}{c|}{ Chemical composition } \\
\cline { 3 - 4 } & & $\mathrm{Al}$ & $\mathrm{Fe}$ \\
\hline \multirow{2}{*}{ Mix 1 } & $495(\mathrm{Fe})$ & 0,00 & 1,00 \\
& $5(\mathrm{Al})$ & 1,00 & 0,00 \\
\hline 2 & 500 & 0,01 & 0,99 \\
\hline Dilution alloy & 610 & 0,00 & 1,00 \\
\hline 3 & 1110 & 0,0045 & 0,9955 \\
\hline
\end{tabular}

A typical melting temperature of steel is about $1500^{\circ} \mathrm{C}$, and the pressure is atmospheric. Introducing the data in the Thermo-Calc software, activity of the elements in the alloys was calculated (Table 2). The specific exergy content of each produced alloy, $\dot{e}_{\text {ch }}$; the total content of exergy, $\dot{E}$; and exergy losses are presented in Table 3.

Table 2. Activity of the elements in the alloys/ mixture

Tabela 2. Aktivnosti elemenata u leguri/smeši

\begin{tabular}{|c|c|c|}
\hline \multirow{2}{*}{ Alloy/Mix } & \multicolumn{2}{|c|}{ Activity $(1500 \circ \mathrm{C}, 1 \mathrm{~atm})$} \\
\cline { 2 - 3 } & $\mathrm{Al}$ & $\mathrm{Fe}$ \\
\hline 1 & 1 & 1 \\
\hline 2 & 0.00049 & 0.97739 \\
\hline 3 & 0.00020 & 0.99028 \\
\hline
\end{tabular}

of exergy decreases during the recycling steps. Therefore, the quality of material decreases during the recycling process. The resource efficiency value calculated for the smelting and dilution is $\psi=$ 0.38 , and R.I. $=1.12$. Both values are unfavorable, due to the large amount of dilution material required to produce alloy 3 .

\section{CONCLUSION}

The method presented in this paper describes calculation of the exergy losses that result from metal recycling contamination. Loss of specific chemical exergy content of metal sreams, can be used as a measure to describe the loss of quality of the metal during the recycling process and to calculate the resource recycling efficiency. The second order losses are relatively low, in relation to 
the total exergy in the system. The largest losses are the losses of the first and third order, because of relations in material losses during the regeneration and the need for introducing the material to dilute the system and improve the quality of products.

Regard to the foregoing, we can conclude that there are two consequences of resources contamination, namely:

- reduction of exergy resources, and

- production of lower quality resources from the higher quality stock resources (as a result of dilution).

\section{Acknowledgements}

The authors wish to acknowledge the financial support from the Ministry of Education, Science and Technological Development of the Republic of Serbia through the projects TR34023 and TR34002.

\section{REFERENCES}

[1] M.B.Castro, J.M.Remmerswaal, J.C.Brezet, A.van Schaik, M.Reuter (2005) A simulation model of the comminution-liberation of recycling streams: Relationships between product design and the liberation of materials during recycling, Int $\mathrm{J}$ Min Proc, 75(3/4), 255-281.

[2] I.Aoki (1998) Entropy and exergy in the development of living systems: A case study of lake-ecosystems, J Phys Soc Jpn, 67(6), 21322139.
[3] H.Dewulf, H.van Langenhove (2003) Exergetic material input per unit of service (EMIPS) for the assessment of resource productivity of transport commodities, Resour Conserv Recycl, 38(2), 161174.

[4] M.Sorin, A.Hammache, O.Diallo (2000) Exergy based approach for process synthesis, Energy, 25(2), 105-129.

[5] R.U.Ayres, L.W.Ayres, K.Martinás (1998) Exergy, waste accounting, and life-cycle analysis, Energy, 23(5), 355-363.

[6] E.D.Schneider, J.J.Kay (1994) Complexity and thermodynamics: Towards a new ecology, Futures, 26(6), 626-647.

[7] S.Alvarado, J.Iribarne (1990) Minimum energy requirements in industrial processes: An application of exergy analysis, Energy, 15(11), 1023-1028.

[8] G.Finnveden, P.Östlund (1997) Exergies of natural resources in life-cycle assessment and other applications, Energy, 22(9), 923-931.

[9] T.J.Kotas (1995) The exergy method of thermal plant analysis, 2nd ed., Krieger Publishing Company, USA.

[10] R.L.Cornelissen (1997) Thermodynamics and sustainable development-the use of exergy analysis and the reduction of irreversibility, Ph.D. Thesis, University of Twente, The Netherlands.

[11] Shukuya, Masanori \& Hammache, Abdelaziz. Introduction to the Concept of Exergy - for a Better Understanding of Low-Temperature-Heating and High-Temperature-Cooling Systems. Espoo 2002. VTT Tiedotteita - Research Notes 2158. 41 p. + app. $17 \mathrm{p}$.

[12] Thermo-Calc Software Version 2015a. http://www.thermocalc.com

\section{IZVOD}

\section{EKSERGIJSKI KONCEPT I NJEGOVA PRIMENA U RECIKLIRANJU METALA}

Dizajn modernih industrijskih proizvoda je takav da oni predstavljaju kompleksne spojeve različitih materijala. Zbog toga se u postupku reciklaže materijala primenjuju procesi usitnjavanja razdvajanja. Međutim materijali se ne mogu u potpunosti razdvojiti i zbog toga dolazi do kontaminacija u reciklažnim tokovima. Zbog toga se kvalitet materijala može smanjivati u svakom narednom reciklažnom koraku. Ovakvi kvalitativni gubici ne mogu se opisati masenim bilansom, $i$ u radu je prikazan eksergijski koncept kao merilo gubitaka kvaliteta, odnosno dat je metod za izračunavanje eksergijskog sadržaja i eksergijskog gubitka. Gubici pripisani reciklaži ili tačnije materijalni gubici, gubici usled kontaminacije drugim metalima i posledično potreba za razblaživanjem, mogu se koristiti kao indikatori gubitka kvaliteta materijala i efikasnosti korišćenja resursa u proizvodnim sistemima. $U$ radu je dat primer proračuna na čeličnom otpadu.

Keywords: eksergijski koncept, reciklaža, kontaminacija, kvalitativni gubici.

Naučni rad

Rad primljen: 18. 10. 2016.

Rad prihvaćen: 21. 11. 2016.

Rad je dostupan na sajtu: www.idk.org.rs/casopis

( 2017 Authors. Published by Inženjersko društvo za koroziju. This article is an open access article distributed under the terms and conditions of the Creative Commons Attribution 4.0 International license (https://creativecommons.org/licenses/by/4.0/ 